\title{
Teachers' Well-Being in Teaching Inclusive Elementary School
}

\author{
Fitri Lestari Issom ${ }^{1}$, Dwi Kencana Wulan ${ }^{2}$, Vinna Ramadhany $\mathrm{Sy}^{3}$ \\ \{fitrilestari@unj.ac.id ${ }^{1}$ \} \\ Faculty of Psychology Education, State University of Jakarta ${ }^{1,2,3}$
}

\begin{abstract}
This study aims to obtain the meaning of Teachers' Well-Being from the phenomenon of regular teachers who teach in an inclusive elementary school. This research uses a Qualitative- Phenomenological approach. The Data Collection Methods are Interviews and Observations through WhatsApp. The subjects of this study are two regular teachers who teach in an inclusive elementary school; in one class that they teach, there are more than two students with special needs. Subject I (EA) is a teacher with a total of 27 years of teaching experience. In 2016, she taught in an inclusive elementary school. At first, she felt tired with the increasing workload and was also surprised by the tantrum behavior of her special needs students. In 2019 she taught grade 1, properly handled five special needs students. Meanwhile, Subject II (WS), who has taught for 16 years in an inclusive elementary school, feels bored at work and wants to have new teaching experiences in other schools. In 2019 she taught grade 6, properly handled 11 special needs students. EA and WS were able to teach well and have an affection for their special needs students because of their experiences and training programs. Both of them have a good relationship with all of the students, fellow teachers, and school principals. Based on the experiences that they have, both of them felt that being an inclusive teacher is a noble job that has an advantage in terms of patience and sincerity.
\end{abstract}

Keywords: Teachers' well-being, inclusive elementary school, students with special needs

\section{Introduction}

The right to have education and freedom from discrimination exists in all Indonesian people. Every Indonesian citizen has the right to have freedom to obtain an education, including for children with special needs.

Children with special needs can not only attend special schools, but a new curriculum is now being introduced, which is known as inclusive, and children with special needs can go to school with normal children. The directorate of special education describes inclusive education as an educational program that allows children with special needs to study alongside their peers in the regular school nearest them [1]. Children with special needs and norma.

children can learn together at these comprehensive schools. They will learn about socialization for children with special needs, and empathy can be taught for normal students.

The government has made the admission of children with special needs compulsory for regular schools in recent years. This is regulated by Regulation No 70 of 2009 Article 4(1) of the Republic of Indonesia Minister of National Education [2]. Regular schools must also consider children with special needs in new student admission and bring up to two children with special needs in one class [3]. 
On that basis, elementary schools must prepare all aspects of the implementation of inclusion programs. The effectiveness of regular schools in providing inclusive education is evidenced by schools' willingness to provide the best education for all students, with the requisite facilities and human resources. It is just that many regular elementary schools are not ready yet. In terms of teachers, for example, in regular elementary schools, teachers who teach are teachers from graduates of the elementary school teacher education study program who have limited knowledge about children with special needs. Sometimes Teachers fail to identify the characteristics of children with special needs and consider them as unintelligent children. This will inevitably affect students with special needs since they do not improve. Regular teachers need to collaborate with special advisory teachers to handle special needs students because advisory teachers have specialized knowledge of children with special needs. Advisory teachers do not attend school every day, however, and does not accompany regular teachers, so teachers must learn the features of each student in their class on their own. Regular teachers who teach in inclusive schools must be provided with the training. The number of students with specific requirements entering elementary schools often strictly enforces school supervision.

This is in line with previous research by Karen Aldrup [4], which shows that teachers believe that more students reporting misbehavior have increased emotional exhaustion (emotional exhaustion). Decrease your work enthusiasm, in any case. Students who misbehave have also been associated with decreased teacher-student relationships. Greater emotional exhaustion and decreased enthusiasm for work have been associated with negative relationships between teachers and students. This clearly states that it will impact their well-being if the teacher is dealing with a larger number of students who misbehave.

In this study, researchers took regular teachers who handled children with special needs in their class of more than two children, with minimal special assistance. The more children who have special needs join the class, the further difficult it would be for the teacher to control the classroom situation. The limited knowledge and experience of teachers who teach in elementary schools are not accessible for them to teach. Based on the results of the interviews and observatory reports, regular teachers teaching in inclusive elementary schools are having some difficulties: There is no clear guidance for children with special needs; there are no specific resources for teachers dealing with children with needs; there is no shortage of direction for dealing with children with special needs. There are no special teachers who are willing and capable of supporting regular teachers to educate children with special needs. The teacher must also provide other normal children with the knowledge that they have special friends so that regular students can build a close connection to children with special needs in the classroom.

In addition to the difficulties regular teachers encounter while teaching, it is often important for teachers to recognize the school as an organization. The school is a convenient place to work for teachers. The physical facilities, such as a comfortable teacher room or relationships between fellow teachers, school principals, and parents, are a perfect illustration. This is consistent with research from Smetackova [5], quantitative method with 2,394 teachers as participants. Burnout, Coping Strategies, Teacher Self Efficacy, Social Support, and Job Satisfaction were the variables studied in this research. The outcome is that the teachers have a light burnout rate on average. The strongest burnout comes from a physical scale; teachers more often use positive coping strategies than negative ones; all variables have a vital burnout relationship. If the teacher has strong self-efficacy, feels satisfied, uses positive coping, and avoids using negative coping, burnout will be lower. Some of these factors can make this regular teacher comfortable teaching kids in their class with special needs. However, it seems that this regular teacher does not have this in reality. 
It is also necessary to help the principal and colleagues as they all continue to work together to give their students the best education. The atmosphere of a pleasant work environment and supportive colleagues can encourage teachers because there are people who can help them through teaching difficulties. Additional assistance is also very much required, such as teaching at all seminars related to the handling of students with special needs, as regular teachers meet children with special needs with various characteristics every year.

To establish positive relations between teachers and students, regular teachers who teach in inclusive schools must be able to cultivate a convenient atmosphere, not pressured, because class environments can be adequately monitored, which can create a good environment for teachers. There may also be a change in conduct among children with special needs. When the teachers know and are close to the pupils, they can also soothe the tantrums.

Shifting regular schools to inclusive schools can increase the burden on teachers. Teachers who previously only taught normal students had to teach normal students and children with special needs in one class when the school transformed into an inclusion. A regular school offering comprehensive education can only provide part of it to its students with limited schools and resources. Based on the interview results conducted by one of the principal of inclusive elementary schools in Jakarta, he said that only extracurricular activities or activities enhancing the right brain's capabilities would increase students' right-brain with special requirements.

Regarding the magnitude of the roles and responsibilities of a regular teacher who teaches in an inclusive school, of course, it is necessary to pay special attention to her welfare so that the teacher can function adequately in school- Teachers' Well-Being. The well-being of teachers at Collie [6] as the well-being of the teachers in the workplace (in this case, school) due to their interpretation of the experience. Collie also said a variety of factors could enhance or reduce the well-being of school teachers. There are three factors: Workload Well-Being, Organizational Well-Being and Student Interaction Well- Being.

Workload Well-Being, which is interpreted positively by regular teachers, will make them not feel stress that leads to stress. Organizational Well-Being, which is interpreted positively, will make regular teachers feel comfortable teaching in inclusive schools because all school elements support each other. Then for Student Interaction Well-Being, if it is interpreted positively, it will help regular teachers get to know students with special needs well and manage the class better. Apart from these three factors, other external factors such as Teacher Stress, Job Satisfaction, General Well-Being, and Sociodemographic.

Every teacher, of course, will have different meanings for welfare. The meaning of wellbeing that differs from regular teachers teaching in inclusive elementary schools depends on their life experiences. Therefore, based on the description above, the researcher wants to know about the description and meaning of Welfare or Teachers' Well-Being in regular teachers who teach in inclusive elementary schools.

\section{Method}

The research method used in this study is a qualitative method with a phenomenological approach. The sampling technique used in this research is Non-probability Sampling in the form of purposive sampling. The research focused on the following: regular teachers who have taught in inclusive elementary schools; in one class they teach, there are more than two students with special needs. In this study, there were two teachers who fit these criteria as research subjects. Data collection techniques used online interviews and observations via WhatsApp application 
in July 2020. The data analyzed started with the conversation type to form a text and then read the entire conversation, mark the statement period, and then code and classify to describe the data obtained. Triangulation method and Source Triangulation have been used to control the validity of the results.

\section{Results and Discussion}

EA and WS are teachers who teach at an inclusive public elementary school in Jakarta. The school was initially a prototype school for inclusion in the X district in 2006/2007, so special needs of multiple disabilities were taken care of. However, in the last two years, the school has strictly selected the new special needs students. In this case, EA and WS have a new experience, involving normal students and students with special needs, who undergo extra workloads and observe students' actions with special needs. Instinctively it made EA and WS exhausted and shocked. If EA and WS can not solve the issues, they can be frustrated and lead to burnout or leave work.

Collie [6] mentions one of them is Workload Well-Being. Workload Well- Being relates to teacher workloads such as teacher administrative duties, meetings, and activities after working hours. EA and WS experience additional workloads such as adjusting regular learning and children with special needs, adjusting the assessment system, and providing additional learning such as learning to read for underprivileged students. Collie [6] mentions that one of them is Workload Well-Being. Workload Well-Being relates to teacher workloads, such as teacher administrative duties, meetings, and activities after working hours. EA and WS experience additional workloads such as adjusting regular learning and children with special needs, adjusting the assessment system, and providing additional learning such as learning to read for underprivileged students.

In this case, there is a slight difference in well-being felt by EA and WS due to their teaching experience at the inclusive school. One of the critical factors in Collie's study in 2015 is the teacher's teaching experience. Subject I (EA) was surprised by the increase in the workload as she did not have 23 years' of experience in private elementary schools in inclusive schools. In 2016, when she started teaching in inclusive elementary schools and taught nine special needs students with different disabilities, EA was shocked by the situation. Although EA had previously been told that she would teach regular students and students with special needs in one class, she did not expect that the number of students with special needs would be large enough. EA does not mind increasing her workload, she works sincerely and patiently. EA is still adapting to work as a teacher in inclusive elementary schools due to her only four years of experience.

Subject II (WS) has been teaching in the school for 16 years, had no idea that she would teach more students more inclusively. She does not really worry about the rise in workload; sometimes, she feels overwhelmed by the situation. She needed a new experience and a new environment for teaching.

In addition to Workload Well-Being, Collie also mentioned Student Interaction Well-Being related to teacher interactions with students and how teachers perceive student behavior and motivation when studying. The difference between EA and WS in this regard is related to the classes they teach. Currently, EA teaches grade 1, and WS teaches grade 6, of course, the student's behavior will be different. EA explained that class 1, where she taught her students, was still good and even though fighting did not make the class chaotic. Meanwhile, in grade 6, 
where WS teaches, there are ABK students who may have gone into puberty because one of them is 16 years old, so that their behavior must be paid attention to properly by WS so that unpleasant events do not occur.

For regular students to communicate with children with special needs, it is just that for $1 \mathrm{st}$ grade, students must acquire a better understanding of their friends with special needs, while WS gives students less awareness as they have experienced in 1 st to 5 th graders.

Collie refers to the organizational well- being in addition to workload well-being and student interaction well-being. Organized well-being is related to school teachers' perception as entities, providing insights into teaching and teaching leadership in schools and culture. This school's working atmosphere is solid in the past year, with teachers still talking about classroom activities. Moreover, all teachers are involved in the decision- making. SS as the Principal, who has only served for one year, positions himself as a colleague so that teachers can freely share their complaints. EA and WS feel comfortable with the relationships they have with the principal and her fellow teachers.

According to Collie, the well-being of regular teachers who teach in inclusive schools can also be seen from their job satisfaction so that they have a complementary view of their work, sociodemographics, and the well-being felt by teachers in general. Between EA and WS, there are slight differences in some of these matters. First, in terms of job satisfaction, EA is satisfied with her job and happy with her current job, while WS is still not satisfied; she wants to experience another teaching experience.

There is a gap of about ten years between them, as seen in terms of both subjects' age. EA is over ten years old. Besides age, teaching is another distinction in which EA has taught regular elementary schools for 23 years, while WS has never taught regular elementary schools.

The correlation between the two is evident from their view on inclusive teachers' occupation, even though their purpose is more or less identical in teaching in elementary schools for 12 years. Both EA and WS recognize the inclusive teaching career as a noble mission, as it can prepare students to succeed. Besides, an inclusion teacher has multiple patience and sincerity. Both are happy with their profession as a teacher. EA and WS also give great praise to the parents of children with special needs because they find it challenging to teach children with special needs.

Then, EA and WS perceive their lives nicely in terms of general well-being. Regardless of their work and life's' difficulties, EA and WS are always confident and always do their best. The findings are being sent to God Almighty after the best efforts have been made. For what they have now, there is a feeling of appreciation.

There are other findings, namely the gratitude of regular teachers who teach at elementary schools, that the author observed in this research. This gratitude emerges from the significance of the teaching experience of the subject. Those who were first exhausted in teaching encountered sympathy and affection until they were eventually pleased to teach children special needs.

\section{Conclusion}

The phenomenon of regular teachers teaching in inclusive elementary schools involves the workload, their interactions with the students, and their close relationship with the principal and their colleagues. If the teacher feels the Well- Being, it can bring positive meaning to his work. 
Based on research conducted at one of the Public Inclusive Elementary Schools in Jakarta, it was found that EA has a pretty good Well-Being with four years of experience teaching in inclusive elementary schools. Her experience teaching in inclusive elementary schools has made EA a more patient and sincere teacher, carries out her job pleasantly, and have a positive outlook regarding her work. Meanwhile, WS, who has taught in inclusive elementary schools for 16 years, feels bored. She wants to have a new experience teaching in another school. She also revealed that teaching in inclusive elementary schools is complicated and demanding. Both WS and EA have complimentary views regarding their work as teachers, namely being more patient, empathetic, and sincere. There is a sense of gratitude or gratitude that is felt based on their experiences while teaching.Apart from their jobs as teachers, EA and WS have an optimistic attitude in their lives to stay physically and psychologically healthy, even though for women, there are monthly things that make their health a little disturbed.

\section{Acknowledgements}

Thank you for the BLU Fund's funding, Faculty of Education in Psychology, UNJ, for research funding. We also express our gratitude to the resource individuals for South Jakarta's Inclusion Elementary School Teachers and the School Principal as the party we make as a source of triangulation. Finally, we also say our gratitude to Nadia Amira, S.Psi, who helped the research process.

\section{References}

[1] T. Handayani, D. Angga, and S. Rahadian, "Peraturan perundangan dan implementasi pendidikan inklusif," Masy. Indones., vol. 39, no. 1, pp. 27-48, 2013, [Online]. Available: http://jmi.ipsk.lipi.go.id/index.php/jmiipsk/article/viewFile/307/178.

[2] Kementerian Pendidikan Nasional Republik Indonesia, "Permendiknas 70 Tahun 2009 tentang Pendidikan Inklusif," Permendiknas 70 Tahun 2009 tentang Pendidik. Inklusif, 2009.

[3] Kemendikbud, “UU No 20 Tahun 2003," Uu, vol. 25, no. 1. pp. 1-14, 2003.

[4] K. Aldrup, U. Klusmann, O. Lüdtke, R. Göllner, and U. Trautwein, "Student misbehavior and teacher well-being: Testing the mediating role of the teacher-student relationship," Learn. Instr., vol. 58, pp. 126-136, Dec. 2018, doi: 10.1016/j.learninstruc.2018.05.006.

[5] I. Smetáčková, I. Viktorova, V. Martanová, A. Pachova, V. Francová, and S. Stech, "Teachers Between Job Satisfaction and Burnout Syndrome: What Makes Difference in Czech Elementary Schools," Front. Psychol., vol. 10, p. 2287, Oct. 2019, doi: 10.3389/fpsyg.2019.02287.

[6] R. Collie, J. Shapka, N. Perry, and A. Martin, "Teacher Well-Being: Exploring Its Components and a Practice-Oriented Scale,” J. Psychoeduc. Assess., May 2015, doi: 10.1177/0734282915587990. 